\title{
Effects of a Programmed Turkish Grammar Instruction on Students' Language Skills
}

\author{
Güner Konedralı 1* \\ ${ }^{1}$ Atatürk Teacher Training Academy, Nicosia, N. CYPRUS
}

Received 21 September 2017 • Revised 11 October 2017 • Accepted 14 October 2017

\begin{abstract}
In this research, effects on grammar and writing achievement of a Turkish language instruction in which a programmed grammar source book followed are explored. Turkish Republic of Northern Cyprus primary schools eighth grade students is the population of this research. The participants of this research are assigned randomly into two groups namely control group $(n=33)$ and experimental group $(n=30)$. The experimental group followed a programmed grammar source book in the teachinglearning sessions in Turkish language instruction, whereas the control group followed a grammar book based on traditional methods. Findings of this research revealed that the experimental group students were more successful in grammar compared to the control group students. However, no significant differences were observed between the experimental and the control group students in terms of writing skills.
\end{abstract}

Keywords: grammar, language teaching, Turkish grammar teaching, programmed instruction

\section{INTRODUCTION}

Speaking is the most distinctive and extraordinary ability of humankind compared to all other creatures. This is the ability which in turn leaded humankind to create language as the most powerful way of communication (Aksan, 1987: 17). Language is almost the most undeniable communication tool which is needed for a better life.

One, who can use language efficiently is not only advantageous in understanding easily what others say, but also his/her messages to others become so clear and understandable.

A form or state of language can be named as "mother tongue" which mostly reflects the social aspects of language. In this contextual social system persons can practice and understand all the aims, values and traditions of the society which in turn lead someone to form a personality and become a member of the society (Göğüş, 1978: 2).

Language, the indispensable communication tool, is also an important ability domain which inclusively contain many learning functions. Students first meet Turkish language as a mother tongue in the context of Turkish language teaching courses as they school life starts.

Multidimensionality of language reflected in five basic skills in Turkish classes namely; reading, listening, speaking, writing and grammar skills. In Turkish classes these basic language skills are usually recommended to be taught in an interrelated and integrated manner. On the other hand grammar and writing are two essential components in any language learning process. In line with that in this research effects on grammar and writing achievement of a Turkish language instruction in which a programmed grammar source book followed are explored. 


\section{Contribution of this paper to the literature}

- We can say that focusing mainly on grammar skills is not enough in improving writing skills in which improving reasoning skills may also be needed.

- Grammar topics should be discussed inclusively within four basic language skills which may give students many opportunities for discovering the connections within the language.

- Analysis revealed that there is no differences between the EG and the CG in terms writing skills achievement means.

\section{LITERATURE REVIEW}

\section{Teaching of Turkish as a Mother Tongue in Turkey}

Teaching of Turkish as a Mother Tongue in Turkey has a long history. During the Ottoman Empire period usually there was no mother tongue concept in educational institutions. Mother tongue first emphasized in educational institutions during the period of Selim the $3^{\text {rd }}$ (Çelebi, 2006: s. 300). Teaching of Turkish has gained importance after the establishment of Turkish Republic. At the first years of Turkish Republic Atatürk's leadership focused on the acceptance of Turkish language as a science. Starting from this period on the teaching of Arabic and Persian languages has been stopped and Turkish language teaching dominated in all formal and general educational institutions by the government (Ağar, 2006). Unfortunately, these valuable progressions decelerated in the following decades. For example, census in 1985 revealed that almost 22.5\% of the population under age 6 were ignorant. A similar result found in 1990 with a $24 \%$. Relying on these issues many reading-writing courses organized but failed to construct a well-established solution (Aş1lığlu, 1993: 6).

Starting from first grade to the end of high school, ineffective and weak instructional strategies and techniques used in Turkish language teaching classes are very important sources of inabilities in Turkish language (Sever, 1995).

Up to 2005 Turkish language teaching were mostly considered as grammar teaching in a behaviourist perspective (Yücer, 2011: s.132).

Starting from 2005 Turkish language teaching mostly has been considered as a body of skills and competencies in a constructivist teaching-learning perspective.

\section{Grammar and Grammar Teaching}

The word "grammar" comes from the word "gram" in Latin which means "symbol and letter" and the word "grammatica" which means the art of reading and writing. In the past grammar was considered as an art of reading and writing. Now, grammar is considered in a more integrated manner not only focusing on the structure of the language but also working on the meaning.

Generally, grammar can be defined as a combination or body of rules and structures of a language. Grammar is so important because it enhance students' understanding and their abilities to express themselves efficiently. Students can also discover and appreciate the beauty of language throughout an efficient grammar teaching. Grammar can also help students in learning a second language.

Grammar can be investigated in two branches namely; (1) school grammar and (2) scientific grammar in which grammar is considered in a more research based manner (Cuq, 2003).

Many researchers like Jean-Pierre Cuq, Besse and Porquier distinguish "school grammar" and "scientific grammar" in terms of content and specify that grammar teaching in schools should be designed in line with the theories and thoughts of educators and language teaching experts instead of linguists (Besse ve Porquier, 1991). Encyclopaedic Dictionary of Linguistics categories grammar under the headings "morphology", "syntax", "linguistics", and "lexico-grammatical multitudes" (Meskhi, 2002:4). In addition to these categories Karl W. Dykema used "school grammar" and M. Kolln used "stylistic grammar in prose teaching" categories (Hartell, 1985:109-110).

Many of the researchers who work on language issues define language concept in an integrated manner with linguistics and rely heavily on the educational and teaching aspects of language by the term "school grammar". School grammar does not focus on every aspect of language and does not include the terms and definitions proposed by expert linguists. School grammar is aligned with the aims and standards of related curriculum mainly emphasizing the aims, expectations and needs of the learners in a pragmatic, meaningful and functional 
perspective. In this respect, good examples and concepts which best fits to the teaching-learning processes are selected practiced by making use of the experimental nature of grammar (Mpanzu, 2011).

According to school grammar perspective, students at the elementary school level first should be educated in such a way that they can fully perform reading and writing. At this level students should be able to understand simple and complex texts, select and comprehend knowledge and concepts. Grammar teaching includes several cognitive skills like ranking, classifying, comparing, relating and detecting similarities and differences. It is so difficult to teach grammar if students fail to perform these tasks in advance. For this reason it is usually recommended to teach some grammatical rules and tasks after age 10 (Güneş, 2013).

\section{Turkish Grammar Teaching in Turkey}

The importance of grammar in improving language skills makes it an indispensable component of mother tongue teaching (Palmer, 1971: 9-10). For this reason in Turkey and many other countries grammar teaching has been considered as a core subject for improving students' reading and writing skills and minimizing language problems. However, the way of teaching grammar was ineffective in solving the already existing language problems. Unluckly these approaches caused some other language problems to emerge. In school settings several sets of grammar rules were taught in detail without full understanding. As a result of these memorizing practices students found grammar as the most boring subject in school (Güneş, 2013).

From a historical point of view it is possible to categorize grammar teaching approaches in Turkey into 3 components namely; behaviourist, cognitivist and constructivist.

In behaviourist and cognitivist approaches generally grammar teaching was practiced traditionally (conventionally). With these approaches grammar teaching shaped around limited number of examples within routine contexts. This way of teaching grammar has been criticized by many educators (Güneş, 2013).

By Turkish Curriculum 2005 new changes and improvements in grammar teaching has been started. In this new curriculum latest developments in education and language teaching were mostly emphasized. With this constructivist Turkish curriculum it was aimed to educate students linguistically, cognitively, personally and socially. In this curriculum grammar teaching was not considered as a separate body but it was taught with an inclusive and integrated way with all the other contents of the curriculum. According to this shift grammar teaching was considered as body including visual reading and representation as well as listening, speaking, reading and writing skills with a spiral approach.

At the elementary school level enabling students to comprehend grammatical rules and procedures intuitively rather than memorizing was the most important virtue of this new curriculum (MEB, 2005).

With this new curriculum, language teaching was not only considered as an important way of improving students' language skills but also improving students' way of thinking and reasoning were aimed. With this new approach, grammar teaching also was considered as a way of improving students' metacognitive skills in addition to having a sense of language (Cuq, 2003). But these new regulations and improvements were not fully successful in solving language teaching problems in Turkey. Although some new valuable skills were added to the new curriculum like criticizing, connecting, analysing, synthesizing and evaluation inability in integrating or harmonizing these skills especially in classrooms did not lead to successful results and outputs (Şahin, 2007). It is possible to say that many of the deficiencies in language skills were relying heavily on the inefficiency of applying the new curriculum.

According to Susar (2001) inefficiencies in Turkish language courses are based on teaching-learning procedures and some other factors correlated with these procedures starting from elementary school to high school. Bölükbaş1 and Saribaş (2011) stated that instructional programs, books, instructional approaches, related institutions, teachers and students were the main sources of Turkish language teaching. However, Arslan et. al (2010) consider the overuse of the traditional teaching approaches as the main source of problem. On the other hand some researchers (e.g., Allright, 1991; Büyükkurt, 1993) define unsuccessful language curriculum practices as the ones where the students are passive recipients mostly in procedural classroom environments.

\section{Grammar Teaching at Middle School Level}

Usually mother tongue education starts in family and flows to mother tongue teaching via courses and become more systematic and structured. Generally a first grader starts to understand that mother tongue has certain rules. At this stage many of the misconceptions and errors of students may not be recovered and influence students' learning in a negative way until middle school level. So the quality of instruction the middle school level is very important in overcoming many errors and misconceptions of students related to language coming from elementary school. 
Table 1. Experimental Design

\begin{tabular}{cccc}
\hline Group & Test & Treatment & Test \\
\hline Control Group & Pretest & Traditional Approach & Posttest \\
\hline Experimental Group & Pretest & Programmed Grammar Source Book Use & Postttest \\
\hline
\end{tabular}

Students at middle school level usually considered as the ones transmitting from concrete operational to formal operational stage. So it is expected that at middle school level students are more capable in understanding abstract concepts and procedures and the instruction can be arrange in that way (Güneş, 2013). In other words it can be said that middle school level is a good starting point in teaching grammar which is mostly abstract for students (MEB Ortaokul Program1, 1993: 11-13).

\section{Grammar Curriculum in TRNC Middle Schools}

Grammar curriculums have being used in TRNC middle schools are aligned with grammar curriculums of Turkey for a long time (Türkiye için İlköğretim Okulu II. Kademe Programı, 1993; KKTC için Ortaokul Öğrenim Program1, 1993). Starting from 2006, Turkish curriculums for 6, 7 and 8 graders in Turkey have started to emphasize many new trends and approaches in developing these curriculums. Although many of these regulations were reflected in the curriculums developed in TRNC some of the dimensions were different than Tukey. There were no differences between Turkey and TRNC in terms of the books used in language classes.

It is always expected to have a perfect harmony among curriculum, instruction and the books used in education. Especially the way of sequencing the topics and tasks in a book is crucial.

Generally in teaching Turkish and specifically in teaching grammar in designing the sequence of the tasks common student errors and difficulties related to grammar should be emphasized and prioritized accordingly. In such a way students can easily overcome their errors and misconceptions.

In this respect, firstly the researcher considered the common student errors done in writing skills at $8^{\text {th }}$ grade in a sequential manner from the mostly occurred to the least occurred (Gögüss, 1978: 342-343; Konedral1, 1997). Later on a programmed source book in line with this understanding was developed. In this research, effects on grammar and writing achievement of a Turkish language instruction for $8^{\text {th }}$ graders in which a programmed grammar source book followed are explored.

\section{METHOD}

In this section research design, sample, data collection and data analysis will be discussed.

\section{Research Design}

In this research, an experimental-control groups pretest-postest design was used. The independent variable for the Experimental Group (EG) was the Turkish Grammar Instruction relying on a detailed programmed grammar source book which is based on students' common errors and difficulties, while the independent variable for the Control Group (CG) was traditional grammar teaching. Two dependent variables were considered - namely, writing skills and grammar skills. Grammar skills were grouped in three task levels as knowledge, comprehension and application. The dependent variables were measured repeatedly before and after the treatments.

Since an experimental design was used in order to test the equality of the groups reading comprehension level and cognitive entry behaviours are measured as covariates (Öncü, 1994). The experimental design of the research is reflected in Table 1.

\section{Sample}

In this research 33 and 30 eight-grade students from an urban middle school in Lefkoşa district were randomly selected to form the control and the experimental groups respectively who were enrolled in the academic year of 2014-2015. In order to test the equality of the groups and check the positions before the treatments start eight-grade reading comprehension test, grammar test, writing test and cognitive entry behaviours test were used.

The topics covered in this research were limited with the eight-grade Turkish Curriculum grammar tasks. 


\section{Data Collection Instruments}

In developing or designing the data collection instruments following procedures were used:

1) The topics covered in the programmed grammar source book are taken from the eight- grade Turkish curriculum.

2) The topics/tasks sequenced according to the common student errors done in writing skills from the mostly occurred to the least occurred.

3) Entry characteristics of the participants were limited with:

a) Reading comprehension test

b) Cognitive entry behaviours

4) Pretest posttest forms were limited with:

a) Grammar test

b) Writing skills test

Reading Comprehension Test: This test first developed by Sever (1995). It is a 60-item multiple-choice test aiming to measure reading, interpretation and connection skills of middle school students. In this research this test was used to determine if the groups were equal or not in terms of reading before the treatments start. This test was pilot tested on a group of students $(n=86)$ similar to the sample of this research. After that the items were experimented in terms of item difficulty, item discrimination and item-total correlation measures. The pilot testing findings revealed that the measures mentioned above were all satisfied the accepted criteria (Everitt, 2002; Field, 2005). The Cronbach $\alpha$ of the test was 0.87 .

Cognitive Entry Behaviours Test: This test is a 100-item multiple choice test developed by the researcher for measuring the cognitive entry behaviours of middle school students which were mainly due to the previous year (7th grade). Like reading comprehension test this test was also used to determine if the groups were equal or not in terms of cognitive entry behaviours before the treatments start. This test was pilot tested on a group of students (n $=78$ ) similar to the sample of this research. After that the items were experimented in terms of item difficulty, item discrimination and item-total correlation measures. The pilot testing findings revealed that the measures mentioned above were all satisfied the accepted criteria (Everitt, 2002; Field, 2005). The Cronbach $\alpha$ of the test was 0.94 .

Grammar Skills Test: This 120-item multiple choice test was developed by the researcher in order to measure the grammar aptitude of the participants. The test has three dimensions -namely, (1) Knowledge, (2) Comprehension and (3) Application. This test was pilot tested on a group of students $(n=254)$ similar to the sample of this research not only to test reliability and related measures (item difficulty, item discrimination and item-total correlation measures) but also construct validity of the test was tested using confirmatory factor analysis. In this respect the findings revealed that, $\chi^{2} / \mathrm{sd}=2.82$, GFI $=0.87$, AGFI $=0.92$ and RMSEA $=0.042$, the test has a threedimensional construct (Tabachnick and Fidell, 2001). The Cronbach $\alpha$ of the test was 0.90 .

Writing Skills Test (Composition): This test was developed by Sever (1995). The aim of using this test was to determine how grammar skills of the students affect their writing skills.

Students were asked to write a composition (essay) with a heading "Introduce Yourself / Who are You?" Writings of the students at pretesting and postteting stages were scored by Turkish language experts using the scoring rubric of Sever (1995).

\section{Procedure}

First of all permission was obtained from the Ministry of Education to conduct this research and the pilot studies. Accordingly 33 and 30 eight-grade students from an urban middle school in Lefkoşa district were randomly selected to form the control and the experimental groups respectively who were enrolled in the academic year of 2014-2015 spring semester.

After the experimental and control groups were formed data collection instruments were pilot tested for reliability and validity.

Then pre-test forms of the instruments namely, writing skills test, grammar skills test, reading comprehension test and cognitive entry behaviours test was administered to the experimental and control groups. Reading comprehension and cognitive entry behaviours tests were used especially to check the equality of the groups.

Afterwards the treatments were applied for 2 weeks in each group. In the experimental group a treatment was used which enriched by the use of a programmed grammar source book. In the control group a traditional approach was used.

The topics in the book used in the experimental group were sequenced considering the common grammar misconceptions and errors of students from the mostly occurred to the least occurred (Gögüss, 1978: 342-343; 
Table 2. Independent samples t-test results regarding the pre-tests scores

\begin{tabular}{|c|c|c|c|c|c|}
\hline Variable & Group & $N$ & $\bar{X}$ & sd & $t$ \\
\hline \multirow{2}{*}{$\begin{array}{c}\text { Reading } \\
\text { Comprehension }\end{array}$} & CG & 33 & 20.90 & 6.70 & \multirow{2}{*}{$.09^{*}$} \\
\hline & EG & 30 & 21.06 & 6.51 & \\
\hline \multirow{2}{*}{$\begin{array}{l}\text { Cognitive entry } \\
\text { behaviours }\end{array}$} & CG & 33 & 35.39 & 9.36 & \multirow{2}{*}{$.26^{*}$} \\
\hline & EG & 30 & 36.03 & 9.77 & \\
\hline \multirow{2}{*}{$\begin{array}{l}\text { Grammar } \\
\text { Skills }\end{array}$} & CG & 33 & 24.55 & 7.33 & \multirow{2}{*}{$.60^{*}$} \\
\hline & EG & 30 & 25.50 & 5.15 & \\
\hline \multirow{2}{*}{ Writing Skills } & CG & 33 & 53.63 & 11.40 & \multirow{2}{*}{$.46^{*}$} \\
\hline & EG & 30 & 55.10 & 13.54 & \\
\hline
\end{tabular}

Table 3. Independent samples t-test results regarding the total and sub-scores of grammar test

\begin{tabular}{|c|c|c|c|c|c|c|c|c|c|}
\hline Sub-Scale & Group & $\mathbf{N}$ & $\bar{X}$ pre & $\bar{X}$ post & Mean Achievement & sd pre & sd post & $t$ & $d$ \\
\hline \multirow{2}{*}{ Knowledge } & CG & 33 & 8.12 & 10.27 & 2.15 & 3.36 & 4.32 & \multirow{2}{*}{$3.22^{*}$} & \multirow{2}{*}{0.82} \\
\hline & EG & 30 & 8.57 & 14.53 & 5.96 & 3.26 & 5.98 & & \\
\hline \multirow{2}{*}{ Comprehension } & CG & 33 & 1.15 & 1.03 & -0.12 & .76 & .88 & \multirow{2}{*}{$2.53^{*}$} & \multirow{2}{*}{0.56} \\
\hline & EG & 30 & 1.2 & 1.46 & 0.26 & .75 & .67 & & \\
\hline \multirow{2}{*}{ Application } & CG & 33 & 15.27 & 21.66 & 6.39 & 4.96 & 6.73 & \multirow{2}{*}{$2.06^{*}$} & \multirow{2}{*}{0.51} \\
\hline & $\mathrm{EG}$ & 30 & 15.7 & 24.90 & 9.20 & 5.38 & 5.89 & & \\
\hline \multirow{2}{*}{ Total } & $C G$ & 33 & 24.55 & 32.94 & 8.39 & 7.33 & 10.23 & \multirow{2}{*}{$3.19^{*}$} & \multirow{2}{*}{0.80} \\
\hline & EG & 30 & 25.5 & 40.90 & 15.40 & 5.15 & 9.59 & & \\
\hline
\end{tabular}

Konedral1, 1997). The sequence used was totally different than the conventional/traditional book used in similar classes and in the control group. Another remarkable difference of the book used in the experimental group was the complementary and prerequisite nature of the flow of the topics. The basic flow of the topics or tasks in that book was as follows: (A) syntactical, (B) morphological and (C) semantical. Programmed grammar source book is partitioned according to the recommendations of Demirel (1995) which is composed of introductory/readiness activities, implementation and evaluation.

After the treatments applied post-test forms of writing skills test and grammar skills tests were administered to the experimental and control groups.

\section{Data Analysis}

In order to test if the dependent variables are normally distributed or not Kolmogorov-Smirnov normality tests used. The findings revealed that for all dependent variables both for the control group, all $0.782 \leq D(33) \leq 0.985$, $0.172 \leq p \leq 0.985$ and the experimental group, $0.453 \leq D(30) \leq 0.876,0.154 \leq p \leq 0.765$, were normally distributed. In addition to this a very high correlation between grammar scores and writing skills scores, $r(63)>0.90, \quad p<.01$, revealed that there is no need to apply multivariate statistics (Maxwell, 2001). So in detecting any potential differences between the experimental group and control group, regarding their writing skills and grammar skills achievement scores independent samples $t$-test procedures were used. Achievement scores were obtained by subtracting the post scores from pre scores. Rest of the analysis relied on these achievement scores. Cohen's (1988) $d$ measures were used to see how much variance was explained by the independent variables. Cohen (1988) characterized $d=0.2$ as small effect, $d=0.3$ as a medium effect and $d=0.5$ as a large effect. The level of significance used throughout the study was .05 .

The equality of the groups were tested regarding pre-writing skills, pre-grammar skills, pre-cognitive entry behaviours and reading comprehension scores by using independent samples $t$-test procedures. As seen in Table 2, there is no difference between the two groups in any of the dependent variables. So we can conclude and accept that the groups are equal at the pre-testing stage.

\section{FINDINGS}

As seen in Table 3, all the sub-scale achievement means are significantly different favouring the EG. Cohen's $d$ effect size measures revealed that the treatment effect is the highest especially in knowledge. But since all the effect sizes are larger than 0.5 we can say that treatment effect is high in all sub-scale variances. 
Table 4. Independent samples t-test results regarding writing skills test scores

\begin{tabular}{cccccccccc}
\hline Group & $\boldsymbol{N}$ & $\bar{X}$ pre & $\bar{X}$ post & Mean Achievement & sd pre & sd post & t \\
\hline CG & 33 & 53.63 & 61.15 & 7.52 & 11.40 & 13.68 & \multirow{2}{*}{$29^{*}$} \\
\hline EG & 30 & 55.10 & 62.70 & 7.60 & 13.54 & 10.84 & 2.13 \\
\hline
\end{tabular}

${ }^{*} p>.05$

As seen in Table 4, there is no significant difference between the EG and the CG in writing skills achievement means.

\section{RESULTS AND RECOMMENDATIONS}

This chapter discusses the findings and results based on the interpretation and the recommendations in relation with the results accordingly.

\section{Results}

In the light of the findings it can be concluded that implementing a programmed well-sequenced grammar source book which emphasizes student errors can lead a better understanding in grammar skills both in lower and upper levels compared to a more conventional approach. Large effect sizes support this conclusion (all $d>0.5$ ).

On the other hand this basic result is also supported by what Gögüş (1978) is recommending in terms of instructional sequence. Similarly Olivia and Amy Benjamin (2007) stated that lessons became helpful when students were informed by what they know about the learning process, were creative, dynamic, socialized, and highly engaging. And, best of all, they were based on an astonishing amount of prior knowledge. That prior knowledge, the students' internal grammar expertise, makes the study of grammar different from every other subject in the curriculum.

Analysis revealed that there is no differences between the EG and the CG in terms writing skills achievement means. So we can conclude that a programmed well-sequenced grammar source book usage and the traditional method both equally affected the writing skills. But in this respect Göğüş (1978) specified that implementations similar to the one used in the EG still could affect writing skills in a positive way. Similarly English Review Group Andrews, R., Torgerson, C., Beverton, S., Locke, T., Low, G., Robinson, A., \& Zhu, D. (2004) found no high quality evidence to counter the prevailing belief that the teaching of the principles underlying and informing word order or 'syntax' has virtually no influence on the writing quality or accuracy of 5 to 16 year-olds.

It is usually recommended to implement grammar lessons naturally in an integrated manner during the revising, editing, and proofreading phases of the writing process (e.g, Chin, n.d). Lack of this approach might be another reason of not helping to improve students' writings in this research. A two-week practice in the experimental group might not be sufficient in improving students' writing skills as well as grammar skills. Cubillo and Hernández (2015) supports this idea by saying "there is not enough class time to practice the grammar structures for the students to internalize such structures and use them correctly in their compositions".

In the light of the findings of this research we can say that focusing mainly on grammar skills is not enough in improving writing skills in which improving reasoning skills may also be needed.

\section{Recommendations}

To summarize, the following recommendations can be offered for researchers, teachers, pre-service teachers, teacher trainers and curriculum experts, in the light of the findings and current practice:

1. Grammar curriculums should not only focus in implementing the basic topics of grammar in addition to this great emphasis should also be given to the meaningful contexts while discussion grammar topics.

2. Grammar programs should be designed in an integrated and cohesive manner which are meaningful for students and help them gaining the skills intuitively.

3. Grammar programs should mainly focus on improving students' comprehension and interpretation skills rather that rote memorization.

4. Grammar topics should be discussed inclusively within four basic language skills which may give students many opportunities for discovering the connections within the language.

5. All grammar instructions should be design and sequenced according to common students errors and misconceptions in a more constructivist way. Student errors can lead students to personalize what they learn and easily reach to powerful generalizations.

6. Grammar instructions should be mutually inclusive with language teaching. 
7. This can be handled with a spiral understanding. Especially pre-service teachers should be educated in line with the findings of this research.

\section{REFERENCES}

Ağar, M. E. (2006). Türkçe öğretiminin tarihçesi. Journal of Human Sciences, 1(1).

Aksan, D. (1987). Türkçenin Gücü. Ankara: Türkiye İş Bankası Kültür Yayınları.

Allwright, D., \& Bailey, K. M. (1991). Focus On The Language Classroom: An Introduction to Classroom Research For Language Teachers. Cambridge, UK: Cambridge University Press.

Andrews, R., Torgerson, C., Beverton, S., Locke, T., Low, G., Robinson, A., \& Zhu, D. (2004). The effect of grammar teaching (syntax) in English on 5 to 16 year olds' accuracy and quality in written composition. Research evidence in education library.

Arslan A., Orhan, S., \& Kırbaş, A. (2010). Türkçe Dersinde Yapılandırmacı Öğrenme Yaklaşımının Uygulanmasına İlişkin Yönetici Görüşleri. Atatürk Üniversitesi Sosyal Bilimler Enstitüsü Dergisi, 14(1), 85-100.

Arslan, A. (2009). Yapılandırmacı Öğrenme Yaklaşımı ve Türkçe Öğretimi. Atatürk Üniversitesi Sosyal Bilimler Enstitüsü Dergisi, 13(1), 143-154.

Aş1lıŏglu, B. (1993). Ortaokullarda Türkçe Öğretimi (Unpublished Doctoral Thesis). Ankara Üniversitesi Sosyal Bilimler Enstitüsü.

Benjamin, A., \& Oliva, T. (2007). Engaging grammar: Practical advice for real classrooms. National Council of Teachers.

Benjamin, O., \& Benjamin, A. (2007). Engaging Grammar: Practical Advice for Real Classrooms. National Council of Teachers of English.

Besse, H. ve Porquier, R. (1991). Grammaire et Didactique des Langues. Didier. Paris Üniversitesi Türkçe Araştırmaları Akademik Öğrenci Dergisi, 1(1), 20-26.

Bölükbaşı C., \& Sarıbaş M. (2011). İlköğretim Birinci Kademe (1, 2, 3. Sınıf). Türkçe Öğretimi Sorunları.

Büyükkurt, G. (1993). Ana Dili Öğretiminde Çağdaş Eğilimler. Türk Ĕgitim Derneği 11. Öğretim Toplantısı. Ankara, Türkiye, 25-26 Mayıs 1993.

Çelebi, M. D. (2006). Türkiye'de Ana Dili Eğitimi ve Yabancı Dil Öğretimi (Unpublished Doctoral Thesis). Erciyes Üniversitesi Sosyal Bilimler Enstitüsü Dergisi, 21(2), 285-307.

Chin, B. A. (n.d). The Role of Grammar In Improving Student's Writing. (2017 September 8). Retrieved from http:// people.uwplatt.edu/ ciesield/graminwriting.htm

Cubillo, P. C., \& Hernández, M. S. (2015). The influence of grammar on english learners' writing accuracy at the school of modern languages. Káñina, Rev. Artes y Letras, Univ. Costa Rica XXXIX, (2), 107-121.

Cuq, J.-P. (2003). Le Dictionnaire de Didactique du Français Langue étrangère et Second. Paris: CLE International.

Demirel, Ö. (1995). Türkçe Programı ve Öğretimi. Ankara, USEM Yayınları - 12.

English Review Group. (2004). The effect of grammar teaching (syntax) in English on 5 to 16 year olds' accuracy and quality in written composition. The EPPI-Centre is part of the Social Science Research Unit, Institute of Education, University of London

Everitt, B. S. (2002). The Cambridge Dictionary of Statistics, 2nd Edition, CUP. ISBN 0-521-81099-X

Field, A. (2005). Discovering Statistics Using SPSS. 2nd ed. London: Sage.

Göğüss, B. (1978). Orta Dereceli Okullarımızda Türkçe ve Yazın Ĕ̆itimi. Ankara: Gül Yayınevi.

Güneş, F. (2013). Grammar Teaching the Constructivist Approach. Journal of Theory and Practice in Education, 9(3), 171-187.

Hartwell, P. (1985). Grammar, Grammars and the Teaching of Gramma. College English. 47(2).

Hernández, P., Cubillo, S., \& Torres-Blanc, C. (2015). On t-norms for type-2 fuzzy sets. IEEE Transactions on Fuzzy Systems, 23(4), 1155-1163.

KKTC Milli Eğitim Bakanlığı. (1993). Ortaokul Programı. KKTC Milli Eğitim Bakanlığı Yayınları.

Konedralı, G. (1997). KKTC Ortaokullarında Okutulan Türkçe Ders Kitaplarının Dil Bilgisi Konuları Açısından Analizi. KKTC MEB Hizmet İçi Eğitim Programı - Eylül 1997.

Maxwell, S. (2001). When to Use MANOVA and Significant MANOVAs and Insignificant ANOVAs or Vice Versa. Journal of Consumer Psychology, 10(1-2):29-30.

MEB, Talim ve Terbiye Kurulu Başkanlığı. (2005). Illköğretim Türkçe Dersi Öğretim Programı ve Kılavuzu. Ankara: MEB Basımevi. 
Meskhi, A. (2002). Systemic Approach in Teaching Grammar to Adult Learners. Retrieved on 23.06.2014 from eric.ed.gov/?id = ED468601

Milli Eğitim Bakanlığı. (1993). İlköğretim Okulu II. Kademe Programı. İstanbul: Milli Eğitim Bakanlı̆̆1 Yayınları.

Milli Eğitim Bakanlığı. (1993). Ortaokul Programı. İstanbul: Milli Eğitim Bakanlı̆̆ Yayınları.

Mpanzu, M. (2011). Quelques Principes Propres A La Didactique De La Grammaire Des Langues Etrangères. Atelier Pédagogique, PUNIV 8070, Cacuaco /Luanda.

Öncü, H. (1994). Eğitimde Ölçme ve Değerlendirme. Ankara: Matzer Matbaası.

Palmer, F. (1971). Grammar. Penguin Books Publ. (Sec. Ed)

Şahin, İ. (2007). Yeni İlköğretim 1. Kademe Türkçe Programının Değerlendirilmesi. İlköğretim Online, 6(2), $284-304$. Sever, S. (1995). Türkçe Öğretiminde Tam Öğrenme. İstanbul: YA-PA Yayınları. Ankara, Türkiye, 25-26 Mayıs 1995.

Susar, F. (2001). Türkçe Öğretiminde Öğretmen Boyutunda Karşılaşılan Sorunlar ve Bunun Öğretmen Performansına Etkileri. Pamukkale Üniversitesi Ĕ̆itim Fakültesi Dergisi, 10, 53-65.

Tabachnick B. G., \& Fidel, L. S. (2001). Using Multivariate Statistics (4th Edition). MA: Allyn \& Bacon, Inc.

Yücer, S. (2011). İnternet Yoluyla Türkçe Öğretimi ve Sorunları. Gazi Üniversitesi Türkçe Araştırmaları Akademik Ögrrenci Dergisi, 1(1), 132-143.

\section{http://www.ejmste.com}

